\title{
Geopolitical Implications of an Economical Force Affected by the Eurozone Crisis: The Case of Cyprus
}

\author{
Nikolaos Papanikolaou ${ }^{1}$
}

\begin{abstract}
:
Cyprus is in many ways unique in Europe. The Greek-speaking part of the island, a member of the euro currency union since 2008, has 790,000 people, about the same population as Columbus, Ohio.

And as the easternmost outpost of the European Union, Cyprus is much closer to Beirut than to Athens. In this paper, we are going to examine Cyprus economy related to the Eurozone crisis. Could Cyprus avoid signing the memorandum?
\end{abstract}

Keywords: Cyprus, economy, EU, crisis.

JEL classification: $\mathrm{HOO}, \mathrm{O1}, \mathrm{EOO}, \mathrm{FOO}$

${ }^{I}$ National Library of Greece,

nkpap85@gmail.com 


\section{Introduction}

The island is located at the juncture of the world island (Eurasia) with Africa. It is on the sea lane of the great maritime highway connecting the Mediterranean Sea through two sea gates-the Suez and Bab al-Mandab-with the Indian Ocean. From there, it links to two other sea gates. These are the Strait of Hormuz, leading to the Persian Gulf, and the Strait of Malacca, connecting to the Pacific. Due to its geostrategic location, throughout its history, external powers have attempted to project their influence over the island.

Cyprus has maintained its strategic importance in contemporary power politics. The "frozen" conflict between the Greek and Turkish Cypriots has brought involvement by the European Union (EU), United Nations, United States, and Turkey. The parties, each with their own agendas, have attempted to work toward some form of resolution of the conflict. Until this is achieved, however, Cyprus will continue to be a great source of instability and conflict in the Eastern Mediterranean. Cyprus has also been an arena of rivalry between Western and Eastern civilizations.

In this geopolitical context, Cyprus has entered the EU as a divided country, a problem that war and diplomacy has failed to solve. Some would say this failure is the result of conflicting outside powers and their interests, which have perennially plagued the island. It has an open, free-market, service-based economy with some light manufacturing. Internationally, Cyprus promotes its geographical location as a "bridge" between East and West, along with its educated English-speaking population, moderate local costs, good airline connections, and telecommunications. Since gaining independence from the United Kingdom in 1960, Cyprus has had a record of successful economic performance, reflected in strong growth, full employment conditions and relative stability

The economy of Cyprus is classified by the World Bank as a high-income economy and was included by the International Monetary Fund in its list of advanced economies in 2001. Erratic growth rates in the 1990s reflected the economy's vulnerability to swings in tourist arrivals, caused by political instability on the island and fluctuations in economic conditions in Western Europe. On 1 January 2008, the country entered the eurozone and adopted the euro as its official currency, replacing the Cypriot pound at an irrevocable fixed exchange rate of CYP 0.585274 per EUR 1.00 .

Cyprus was once known as the type of place where the Serbian strong man Slobodan Milosevic did his banking. But the Central Bank, which also regulates the financial sector, led a clean up effort to meet standards that enabled Cyprus to join the European Union in 2004. Foreign diplomats say the island is now considered a legitimate banking hub. Despite sharing Greece's language, Cypriots take umbrage at comparisons with their hard-pressed neighbor. The country is considered business-friendly, in contrast to Greece, with its obstinate bureaucracy. And the 
Cypriot economy had long been more vibrant, growing virtually every year after the war in 1974 until 2009. Until the crisis hit, unemployment was less than 4 percent, and the island was a magnet for foreign workers. Since the debt crisis started at 2008, first in USA, and from 2009 coming to Europe however, all these facts have changed dramatically Cyprus and Europe.

\section{Methodology}

The eurozone crisis cannot be explained through one single factor; a collusion of myriad elements ensured the spiralling from a small crisis in Greece to one engulfing the whole of the eurozone and the EU (Allegret et al., 2016; Thalassinos et al., 2015a; 2015b; Thalassinos and Stamatopoulos, 2015). There are at least two factors that explain the crisis, beginning of course with the 2008 global economic crisis. The impact on the EU was extreme:

i) real GDP growth in the EU dropped from 3\% in 2007 to $0.5 \%$ in 2008 and to $-4.2 \%$ in 2009 ;

ii) unemployment in the EU increased from $7.2 \%$ in 2007 to $9.7 \%$ in 2010.

The problem of a lack of growth and unemployment still dog the EU. These two specific issues make the issue of sovereign debt crucial. The global economic crisis that began in the late 2000s eventually gave rise to the debt crisis, first in Dubai and then in Greece. In most cases, private debt translated into public debt in order to keep markets and moral hazard in the banking and financial sectors at bay. Portugal, Ireland, Greece and Spain (the crudely labelled "PIGS") are all suffering from sovereign indebtedness, albeit for different reasons (Boldeanu and Tache, 2016; Duguleana and Duguleana, 2016).

In each case the respective governments found it difficult to borrow money from the international markets. Furthermore, with private debt quickly becoming government debt and the impact of budgetary austerity on public sector spending - agreed under duress in exchange for bail-out money - has resulted in less consumer demand, lower wages, low growth, decreasing tax revenues and more social and political unrest; the factors which impact on a government's ability to pay down sovereign debt (Chronis and Zombanakis, 2016).

The Mediterranean country (Cyprus) has become the fifth Eurozone nation to hold out its hand for an international rescue. While the smallest of the bunch to seek relief, Cyprus highlights the European Union's increasingly stressed resources as it wrestles with weakening economic conditions. The aid request followed Fitch's downgrade of the island's stressed banks to "junk" status. The credit cut means the country has lost it investment status with the trio of the argest and most influential rating agencies. Fitch said in a statement, "Cypriot banks will require substantial injections of capital in order to secure confidence in their financial viability." 
Cyprus, saddled with Greek private sector debt, could need as much as 10 billion euros (\$12 billion) in bailout funds. Last year, Cyprus, frozen out of international debt markets, turned to Russia rather than to the Union. The Russian government lent the Cypriot government $€ 2.5$ billion at a below-market rate of 4.5 percent. Russia's motivations are murky. One theory is that Russia was just protecting the interests of Russian companies with operations in Cyprus and helping its closest ally in the European Union.

Another theory, denied by the Cypriot government, is that Russia hopes for preferential treatment in getting rights to explore the natural gas reserves that are believed to lie off the Cypriot coast. But Russia is not expected to want to increase its risk in Cyprus with another loan.

In 2012 economical situation was getting worse, and a default was on its way. According to the official figures, Cypriot debt is $73 \%$ of GDP, much lower than the European average of $88 \%$, and the deficit is $4.5 \%$, lower than in the UK and France. In a fight against the time, the President was trying to borrow 5 billion euros from supposedly "anti-imperialist" Russia. The answer from Russia this time was a big "Nyet".

In November 2012, Cyprus asked officialy for help from Troika, the European Union, the European Central Bank and the International Monetary Fund, to get financial aid and signed a memorandum in December 2012 for the recapitalization of Cyprus biggest banks. The Troika estimated the amount required to recapitalise the banks at 10 billion euros. At 10 billion, the rescue package will sky rocket Cyprus's public debt from $72 \%$ of GDP to above $130 \%$, by turning bank debt into public debt. This debt figure means Cyprus being trapped under long term international financial supervision, with repeated austerity packages.

The big dispute in the negotiations between the political party AKEL (the government at that period) and the Troika was not the amount of the cuts, but that the Troika demanded most austerity measures be taken during 2012-2013, whereas AKEL tried to shift them towards 2015-2016. The only battle from AKEL was to try to postpone the cuts until after the end of its own presidency. The austerity measures follow the well-known Greek recipe, including dismantling of labour laws, union rights, and collective bargaining agreements. Unemployment is already officially at $11 \%$ and $25 \%$ for people under 25 years old, and $23.6 \%$ of the population is already threatened by poverty and social exclusion.

\section{Conclusions}

The crucial question is if Cyprus could avoid signing the memorandum? was there really another way out to overcome the difficult financial situation for the government? 
A government of a left party should have never signed the memorandum, because it leads Cypriot society into mass poverty, unemployment, and misery. The real fight should have been for a program of transitional demands, based upon workers' self management and control and the social planning of the economy to meet the needs of the people and not for the profits of bankers. In a sense, the election of a left party in the government was historic. For the first time a president in Cyprus spoke in the name of communism and the left, in the name of the working class. But it was clear that AKEL's victory would not open the way for socialism in Cyprus. The President repeated several times that AKEL's "ideology is Cyprus". Before the election, he had repeated contacts with industrialists and bankers to reassure them that a government of AKEL would pose no threat to their class interests.

In the five-year period, March 1, 2008 to February 28, 2013, Cyprus became the one and only European Union member state to be governed by a communist party. In ruling Cyprus for five years, the communist party made the island a case study on how destructive economic populism can be.

Will the Cyprus economy turn back things and return to path of economic growth? After some difficult years, with strict financial policy and control, the answer is probably yes. The island has all the economical, geographical, and geopolitical reasons to succeed, bringing back its real mission, being a strategical force in the Mediterranean and in the EU.

\section{References:}

Alemdar, S. 2009. Strategic Importance of Cyprus. Nicosia, Cyprus.

Allegret, J.P., Raymond, H. and Rharrabti, H. 2016. The Impact of the Eurozone Crisis on European Banks Stocks, Contagion or Interdependence. European Research Studies Journal, 19(1), 129-147.

Boldeanu, T.F., Tache, I. 2016. The Financial System of the EU and the Capital Markets Union. European Research Studies Journal, 19(1), 60-70.

Bordonaro, F. 2009. Rediscovering Spykman. Exploring Geopolitics.

Chronis, P., Zombanakis, G. 2016. An Evaluation of Policies for Fiscal and External Sustainability during the Recent Greek Economic Crisis. European Research Studies Journal, 19(1), 34-44.

Constantinou, C., Richmond, O. The Long Mile of Empire: Power, Legitimation and the UK Bases in Cyprus. Mediterranean Politics, 10(1).

Duguleana, L., Duguleana, C. 2016. Structural Aspects of the European Union Economy. European Research Studies Journal, 19(1), 93-128.

Henn, F. 2007. Cyprus: The Geo-strategic Dimension. Contemporary Review, 1(1).

Ker-Lindsay, J. 2007. A Difficult Transition to a New Relationship: Britain and Cyprus in the European Union. Journal of Contemporary European Studies, 15(2).

Orphanides, A. 2016. What Happened in Cyprus? The Economic Consequences of the Last Communist Government in Europe. The Cyprus Bail-In, 163-207.

Thalassinos, I.E. and Dafnos, G. 2015a. EMU and the process of European integration: Southern Europe's economic challenges and the need for revisiting EMU's institutional framework. Chapter book in Societies in Transition: Economic, 
Political and Security Transformations in Contemporary Europe, 15-37, Springer International Publishing, DOI: 10.1007/978-3-319-13814-5_2.

Thalassinos, I.E., Stamatopoulos, D.T. and Thalassinos, E.P. 2015b. The European Sovereign Debt Crisis and the Role of Credit Swaps. Chapter book in The WSPC Handbook of Futures Markets (eds) W. T. Ziemba and A.G. Malliaris, in memory of Late Milton Miller (Nobel 1990) World Scientific Handbook in Financial Economic Series Vol. 5, Chapter 20, pp. 605-639, ISBN: 978-981-4566-91-9, (doi: 10.1142/9789814566926_0020).

Thalassinos, I.E. and Stamatopoulos, Th. 2015. The Trilemma and the Eurozone: A PreAnnounced Tragedy of the Hellenic Debt Crisis. International Journal of Economics \& Business Administration, 3(3), 27-40.

Yilmaz, S. 2009. Power Politics and Cyprus. Beykent University. 